\title{
OPTIMALISASI PERAN DEWAN PENGAWAS SYARIAH PADA LEMBAGA KEUANGAN MIKRO SYARIAH (Studi Kasus di Assosiasi Koperasi Warga NU Jepara)
}

\author{
Ulin Nuha \\ ${ }^{1}$ Institut Agama Islam Negeri Kudus, Kudus \\ $\triangle$ dzulvikri99@gmail.com
}

Abstract : This study aims to find out the supervision carried out by the Sharia Supervisory Board, and try to analyze the role and function of the Sharia Supervisory Board in supervising shari'ah financial institutions, especially for ASKOWANU Jepara. This research is descriptive qualitative research, where data collection is carried out from various sources in the form of books, magazines, newspapers and documents related to the supervision of sharia financial institutions.

The results of this study illustrate that basically the supervision of sharia financial institutions has two systems, namely supervision of aspects: (i) financial conditions, compliance with the provisions of financial institutions in general and prudential principles, and (ii) compliance with sharia principles in the operational activities of institutions Islamic finance. In this regard, the structure of supervision of sharia financial institutions is more multilayer in nature, which would ideally consist of a system of internal supervision carried out by Sharia Supervisory Board, which is more in-depth and carried out so that there are mechanisms and control systems for the interests of management and external supervision systems. by DSN which basically to meet the interests of customers and public interests in general.

Keywords $\quad$ :Optimization, Sharia Supervisory Board, Sharia Micro Financial Institutions

\section{LATAR BELAKANG}

Lembaga keuangan mikro merupakan salah satu alat yang cukup penting untuk mengangkat tingkat perekonomian masyarakat saat ini. Pelaksanaan dan operasional lembaga keuangan mikro selain dilakukan dengan pola simpan pinjam juga dapat dilakukan dengan pola bagi hasil di bawah sistem keuangan syariah. Lembaga yang dapat menjalankan peran sebagai lembaga keuangan mikro syariah saat ini adalah Koperasi Jasa Keuangan Syariah (KJKS) dan Baitul Maal Wat Tamwil (BMT) (Soemitra, 2017). Seiring perkembangannya, peran BMT semakin dibutuhkan sehingga untuk mengakomodir hal itu terjadi perubahan yang pada awalnya Koperasi Jasa Keuangan Syariah (KJKS) menjadi Koperasi Simpan Pinjam dan Pembiayaan Syariah (KSPPS).

Seiring dengan tumbuh dan kembang Lembaga Keuangan Mikro berbasis syariah di Indonesia, pengawasan oleh Dewan Pengawas Syariah (DPS) menjadi 
perhatian oleh semua pihak. Sebagai bagian dari organ Dewan Syariah Nasional (DSN) di Koperasi Simpan Pinjam dan Pembiayaan Syariah (KSPPS), DPS memiliki tugas dan fungsi yang penting dalam mengawal kegiatan operasional KSPPS agar sesuai dengan prinsip-prinsip syariah. Untuk melaksanakan tugas dan wewenang tersebut dibutuhkan standar kompetensi keilmuan syariah dan operasional yang memadai.

Oleh karenanya diperlukan adanya pengawasan yang melekat pada setiap orang yang terlibat di dalam aktivitas keuangan berupa motivasi keagamaan maupun pengawasan melalui kelembagaan. Di dalam menjalankan fungsi kelembagaan agar operasional Lembaga Keuangan Syariah tidak menyimpang dari tuntutan syariah Islam, maka di adakan "Dewan Pengawas Syariah". Dewan Pengawas Syariah merupakan dewan pakar ekonomi dan ulama yang menguasai bidang fiqh mu'amalah (Islamic commercial jurisprudence) yang berdiri sendiri dan bertugas mengamati dan mengawasi operasional lembaga keuangan syariah dan produk-produknya agar sesuai dengan ketentuan-ketentuan syariat Islam, yaitu dengan mengawasi secara teliti bagaimana bentuk-bentuk perikatan/akad yang dilaksanakan oleh lembaga keuangan syariah. Perekrutan Dewan Pengawas Syariah pada lembaga keuangan syariah seharusnya dilakukan secara terbuka dan transparan dengan melibatkan pihak yang independen, seperti pemilihan anggota KPU oleh tim yang independen atau pemilihan Hakim Agung oleh Komisi Yudisial. Hal mana agar orang yang terpilih sebagai anggota atau ketua Dewan Pengawas Syariah adalah orang mempunyai kemampuan di bidang syariah muamalah dan perbankan secara umum, sehingga mampu memberikan penilaian dan pengawasan secara maksimal dalam rangka menjaga ke-syariah-an produk-produk lembaga keuangan syariah.

Sejalan dengan perkembangan lembaga-lembaga keuangan syariah, ulama semakin tertuntut untuk turut serta dalam memberikan masukan untuk kemajuan lembaga tersebut, Majelis Ulama Indonesia (MUI) membentuk Dewan Syariah Nasional (DSN) yang dianggap sebagai langkah efisien untuk mengkoordinasikan ulama dalam menanggapi isu-isu yang berhubungan dengan masalah ekonomi atau keuangan. Disamping itu, DSN diharapkan berfungsi sebagai pendorong penerapan ajaran Islam dalam kehidupan ekonomi. Oleh karena itu, DSN berperan serta secara proaktif dalam menanggapi perkembangan masyarakat Indonesia dalam bidang ekonomi dan keuangan.

Dalam upaya memurnikan pelayanan institusi keuangan syariah agar benarbenar sejalan dengan ketentuan syariah Islam, keberadaan Dewan Pengawas Syariah (DPS) mutlak diperlukan. DPS merupakan lembaga kunci yang menjamin bahwa kegiatan operasional institusi keuangan syariah sesuai dengan prinsipprinsip syariah. 2 Merujuk pada surat keputusan Dewan Syariah Nasional No. 3 Tahun 2000, bahwa Dewan Pengawas Syariah (DPS) adalah bagian dari lembaga 
keuangan syariah yang bersangkutan, dan penempatannya atas persetujuan Dewan Syariah Nasional (DSN). Dalam rangka mengefektifkan pelaksanaan tugas Dewan Pengawas Syariah diperlukan upaya peningkatan pengetahuan DPS tentang operasional perbankan, serta intensitas keterlibatannya dalam program sosialisasi atau promosi pada penduduk lokal.

Selain dari itu, lahirnya lembaga pengawas seperti DPS merupakan langkah maju dalam dunia keuangan di tanah air, terutama disaat terjadinya moral hazard di kalangan praktisi keuangan, dimana mereka dengan seenaknya berbuat curang, menipu dan membungakan uang, yang tidak hanya berakibat pada krisis keuangan semata, tapi juga berakibat pada hilangnya trust masyarakat terhadap beberapa lembaga keuangan di Indonesia. Oleh karena itu, sebagai lembaga yang bertugas mengawasi dan memastikan praktek lembaga keuangan syari'ah sesuai dengan prinsip-prinsip syari'ah, tentu DSN dan DPS merupakan tugas mulia dalam pandangan masyarakat dan terlebih di hadapan Allah SWT.

Berdasarkan hal tersebut di atas, penelitian ditujukan untuk mengupas sekelumit tentang peran dan fungsi DPS serta mencoba menganalisa efektifitas tugas DPS dalam mengawasi lembaga keuangan syari'ah yang ada di ASKOWANU Jepara pada khususnya.

\section{Teori dan Metode Penelitian}

\subsection{Profil Lembaga Keuangan Mikro Syariah}

Koperasi Simpan Pinjam Pembiayaan Syariah (KSPPS) atau sebelumnya di sebut Koperasi Jasa Keuangan Syariah (KJKS) terlahir dari Baitul Maal wat Tamwil (BMT) merupakan entitas keuangan mikro syariah yang unik dan spesifik khas Indonesia. Menurut Peraturan Menteri Koperasi dan Usaha Kecil dan Menengah Republik Indonesia tentang Pelaksanaan Kegiatan Usaha Simpan Pinjam Dan Pembiayaan Syariah Oleh Koperasi, Pasal 1 disebutkan bahwa Koperasi Simpan Pinjam dan Pembiayaan Syariah (KSPPS) adalah koperasi yang kegiatan usahanya meliputi simpanan, pinjaman dan pembiayaan sesuai prinsip syariah, termasuk mengelola zakat, infaq/sedekah, dan wakaf (Hidayat, Farid: 2016).

BMT dapat menjalankan berbagai jenis kegiatan usaha, baik yang berhubungan dengan keuangan maupun non keuangan.Pertama, penghimpunan dana zakat, infaq, dan shadaqah untuk disalurkan ke para mustahiq (penerima dana zakat). Kedua, penghimpunan dana BMT dengan mobilisasi dana dan mengembangkannya dalam aneka simpanan. Ketiga, penyaluran dana melalui kegiatan pembiayaan usaha mikro dan kecil (Ismanto,2015). 
ASKOWANU Jepara adalah salah satu perkumpulan BMT-BMT yang cukup maju. Tidak hanya itu, perkembangan anggota BMT pun bisa tertata dengan rapi. Jumlah kantor cabang yang semakin banyak menunjukkan adanya kemajuan dalam bidang finansial. Ini adalah bentuk kemajuan yang di tunjukkan oleh BMT-BMT dibawah naungan ASKOWANU pada umumnya. Tampak, Sedikit demi sedikit peningkatan itu mulai muncul bersamaan dengan berjalannya era globalisasi. Namun apakah mereka sudah siap atau belum sama sekali bahwa mereka akan menghadapi dunia di era globalisasi ini? ASKOWANU Jepara harus bekerjasama dengan masyarakat yang harus dipandu atau yang masih harus di pantau. Untuk mengembangkan kesejahteraan rakyat, ada beberapa program yang diberikan ASKOWANU Jepara kepada warga masyarakat Jepara. Karena dengan tersusunnya suatu program yang rapi akan terwujud suatu pekerjaan dan hasil yang memuaskan.

Secara geografis ASKOWANU Jepara terletak di Jalan Pemuda No. 51 Potroyudan Kecamatan Jepara Kabupaten Jepara. Sedangkan BMT-BMT yang berada dibawah naungannya, meliputi 13 BMT dan memiliki sekitar 42 kantor cabang yang tersebar di wilayah kabupaten Jepara.

\subsection{Model Penelitian}

Penelitian ini menggunakan model kualitatif deskriptif, di mana subjek penelitian (informan) tidak harus banyak. Namun, yang lebih penting dalam penelitian kualitatif adalah adanya anggapan bahwa subjek yang dipilih adalah pihak yang paling mengetahui tentang informasi yang diharapkan oleh peneliti (Idrus. 2009: 95).

\subsubsection{Data Primer}

Data primer yaitu data yang diperoleh atau dikumpulkan oleh peneliti secara langsung dari sumber datanya (Suryana, 2010). Data ini bersumber dari hasil wawancara yang dilakukan oleh peneliti dengan subjek penelitian (Ketua beserta Pengurus ASKOWANU Jepara).

\subsubsection{Data Sekunder}

Data sekunder yaitu data yang diperoleh atau dikumpulkan peneliti dari berbagai sumber yang telah ada (Suryana, 2010). Data ini bersumber dari bukubuku, penelitian terdahulu, dan internet.

\subsubsection{Wawancara}

Wawancara adalah suatu cara pengumpulan data melalui proses tanya jawab yang berlangsung satu arah, artinya pertanyaan diajukan dari pihak yang mewawancarai (peneliti) dan jawaban diberikan oleh pihak yang diwawancara (responden). Peneliti juga dapat menyediakan berbagai pertanyaan yang akan 
diajukan dengan membuat daftar pertanyaan terlebih dahulu (Fathoni, 2011: 105). Dalam penelitian ini peneliti melakukan wawancara terhadap Dewan Pengawas Syariah atau pihak yang bersangkutan di ASKOWANU Jepara.

\subsubsection{Dokumentasi}

Dokumentasi merupakan teknik pengumpulan data dengan cara mencari data mengenai hal-hal atau variabel yang berupa catatan, transkrip, buku, surat kabar, majalah, prasasti, agenda dan sebagainya (Suharsimi, 2006: 231). Dalam penelitian ini, metode dokumentasi dilakukan dengan cara mengambil data dokumen pendukung yang berkaitan dengan persoalan penelitian ini.

\subsubsection{Teknik Analisis Data}

Penelitian deskriptif, yaitu penelitian yang dimaksudkan untuk memberikan data yang seteliti mungkin tentang manusia, keadaan, atau gejala-gejala lainnya (Soekanto, 1986:10). Penelitian deskriptif (descriptive researce) hanya menggambarkan dan meringkaskan berbagai kondisi, situasi atau berbagai variabel. Penelitian deskriptif berkaitan dengan pengumpulan data untuk memberikan gambaran atau penegasan suatu konsep atau gejala, juga menjawab pertanyaan-pertanyaan sehubungan dengan status subyek penelitian pada saat ini, misalnya sikap atau pendapat terhadap individu organisasi dan sebagainya. Data deskriptif pada umumnya dikumpulkan melalui metode pengumpulan data, yaitu wawancara atau metode observasi. Penelitian deskriptif terbatas pada usaha mengungkapkan suatu masalah, keadaan atau peristiwa sebagaimana adanya. Sifatnya sekedar mengungkap fakta (fact finding). Hasil penelitian lebih ditekankan pada pemberian gambaran secara obyektif tentang keadaan sebenarnya dari obyek yang diselidiki. Akan tetapi, guna mendapatkan manfaat yang lebih luas, di samping mengungkap fakta, diberikan interpretasi yang cukup kuat (Wiratha, 2005: 154).

\section{Pembahasan}

\subsection{Dewan Pengawas Syariah}

Dewan Pengawas Syariah atau dikenal dengan DPS merupakan organ dari Dewan Syariah Nasional (DSN) di lembaga keuangan syariah. Firdaus (2007) Dewan pengawas syariah adalah suatu badan yang bertugas mengawasi pelaksanaan keputusan DSN di lembaga keuangan syariah. DPS diangkat dan diberhentikan di lembaga keuangan syariah melalui RUPS setelah mendapat rekomendasi dari DSN. Tugas utama Dewan Pengawas Syariah adalah mengawasi kegiatan usaha lembaga keuangan syariah agar sesuai dengan ketentuan dan prinsip syariah yang telah difatwakan oleh Dewan Syariah Nasional. Fungsi utama Dewan Pengawas Syariah adalah sebagai penasehat dan pemberi saran kepada direksi, pimpinan unit usaha syariah dan pimpinan kantor cabang syari`ah 
mengenai hal-hal yang terkait dengan aspek syariah dan sebagai mediator antara lembaga keuangan syariah dengan Dewan Syariah Nasional dalam mengkomunikasikan usul dan saran pengembangan produk dan jasa dari lembaga keuangan syariah yang memerlukan kajian dan fatwa dari Dewan Syariah Nasional (DSN-MUI, 2018). DPS ini secara organisasi bertanggungjawab kepada DSN MUI pusat, kredibilitasnya kepada masyarakat, dan secara moral bertanggungjawab kepada Allah Swt (Soemitra, 2017).

Dewan Pengaswas syariah adalah dewan yang dipilih oleh Koperasi yang bersangkutan berdasarkan Keputusan Rapat Anggota, yang beranggotakan alim ulama yang ahli dalam syariah yang menjalankan fungsi dan tugas sebagai pengawas syariah pada koperasi yang bersangkutan dan berwenang memberikan tanggapan atau penafsiran terhadap fatwa yang dikeluarkan oleh DSN-MUI.

Merujuk pada Peraturan Menteri Koperasi dan usaha kecil dan menengah Nomor 16/Per/M.KUKM/IX/2015 Pasal 1 Ayat 6. Terkait dengan kewajiban adanya DPS di masing-masing BMT Permen Nomor 16/Per/M.KUKM/IX/2015 Pasal 14 ayat 1 menyebutkan Bahwa KSPPS dan Koperasi penyelenggara usaha Simpan Pinjam dan Pembiayaan Syariah wajib memiliki Dewan Pengawas Syariah.

Dewan Pengawas Syariah, yang selanjutnya disebut DPS seharusnya memiliki peran dan tugas yang menjadi ujung tombak perkembangan lembaga keuangan syariah tersebut, mengapa demikian ? karena Dewan Pengawas Syariah mesti melihat secara teliti bagaimana bentuk-bentuk perikatan atau akad yang dilaksanakan oleh institusi keuangan syariah. Kelegalan dalam bentuk-bentuk pengembangan perikatan atau akad syariah sesuai dengan Hukum Islam sangat penting bagi citra dan kredibilitas lembaga keuangan syariah di mata masyarakat. Untuk itu peran dari Dewan Pengawas Syariah secara optimal sangatlah dibutuhkan, baik perannya sebagai pengawas manajemen maupun administrasi yang berhubungan dengan ke-syariah-an operasional sebuah lembaga keuangan Islam.

Kelembagaan Dewan Pengawas Syariah itu sendiri saat ini dinilai belum independen sebagaimana yang dicita-citakan, sebab pada dasarnya pembentukan Dewan Pengawas Syariah adalah atas permintaan dari Rapat Anggota Tahun(RAT). Bahwa pemegang terbesar saham pada suatu lembaga keuangan Syariah berhak menentukan orang yang diusulkan untuk duduk di Dewan Pengawas Syariah. Hal ini akan berakibat kepada tidak independennya Dewan Pengawas Syariah dalam menjalankan tugas pengawasan. Akibatnya Dewan Pengawas Syariah sedikit banyaknya terikat dalam mengeluarkan saran dan pendapat, karena ditakutkan akan bertentangan dengan kebijakan yang diminta oleh Rapat Anggota Tahun(RAT), akhirnya fungsi dan peran DPS hanya sebagai lipstick sekedar memenuhi perangkat yang diharuskan oleh peraturan perundang-undangan. Padahal seharusnya Dewan Pengawas Syariah, adalah dewan yang bersifat independen sebagai perpanjangan tangan DSN dan ditempatkan pada lembaga keuangan syariah yang melakukan kegiatan usaha berdasarkan prinsip syariah dengan fungsi yang diatur oleh DSN dan BI dan perangkat undang-undang lainnya. 
Dengan adanya sistem sebagaimana yang dijelaskan menjadikan DPS lebih leluasa dan terbuka dalam mengemukakan dan mengkritisi kebijakan dan operasional dari lembaga keuangan Syariah.

Posisi DPS pada lembaga keuangan Syariah dinilai sangat strategis dalam menilai kebijakan operasional lebih dalam. Misalnya melakukan penelaahan terhadap produk pembiayaan murobahah, tabungan mudharabah. Sebab selama ini ditenggarai bahwa beberapa produk yang telah dijalankan beberapa lembaga keuangan syariah tersebut dinilai dari tingkat bonus dan bagi hasil masih menyesuaikan dengan tingkat bunga yang berlaku di lembaga keuangan konvensional. Mengapa demikian, karena lembaga keuangan syariah tidak mau kehilangan kesempatan untuk meraih nasabah sebanyak-banyaknya, di sisi lain nasabah juga masih berpikir keuntungan yang diberikan oleh lembaga keuangan syariah apakah menabung di lembaga keuangan syariah memberikan nilai/benefit sejajar dengan yang diberikan oleh lembaga keuangan konvensional. DPS selaku pengawas dan pemberi saran kepada manajemen bank (Direksi) seharusnya sebagai institusi keuangan syariah jangan terjebak dengan motif meraup nasabah sebanyak-banyaknya yang pada akhirnya terjadilah penyimpangan dalam akadakad yang telah ada. Lembaga keuangan Syariah harus menerapkan produkproduk dengan prinsip akad syariah, baik itu wadi'ah maupun akad mudharabah haruslah berdasarkan keadaan atau keuntungan yang didapatkan oleh lembaga keuangan syariah secara ril, bukan mensejajarkan benefit yang diberikan kepada nasabah menyesuaikan tingkat bunga di lembaga keuangan konvensional.

\subsection{Optimalisasi peran DPS dalam Lembaga Keuangan Syariah}

Fungsi yang diemban DSN untuk melahirkan fatwa di bidang keuangan merupakan bagian dari gelombang kebangkitan ijtihad yang sangat luar biasa terutama di bidang ekonomi, finansial, dan perbankan kontemporer tidak saja di negara-negara Arab dan Islam tetapi juga di seluruh penjuru dunia. Perkembangan lembaga-lembaga keuangan Islamlah yang mendorong berkembangnya ijtihad, baik pada level individu, lembaga maupun dunia Islam.

Pada sisi lain kenyataan tersebut telah menghapus dugaan bahwa selama ini ijtihad dilakukan oleh mujtahid tertentu dan bersifat informal. Padahal, ijtihad harus dilakukan oleh para ahli yang berkompeten dan memiliki kemampuan yang luar biasa dalam melahirkan sebuah hukum, bekerjasama dengan pemerintah sehingga ia dapat diberlakukan sebagai perundang-perundangan. Jika tidak ia hanya akan bersifat teoritis semata dan dampaknya dapat terjadi benturan antara pemerintah dan mujtahid. DSN dalam hal ini sudah melakukan ijtihad kolektif sekaligus melakukan positivisasi terhadap hasil ijtihad, sehingga mengikat semua pihak, antara lain Bank Indonesia dan pihak-pihak terkait lainnya untuk menerima bagian dari jalan Islam dalam ekonomi Islam di Indonesia.

Walaupun keberadaan DSN dan DPS sebagai lembaga pengawas dalam lembaga keuangan syariah dijamin oleh Undang-Undang Nomor 10 tahun 1998, peran, fungsi DSN dan DPS belum berjalan secara optimal. Pada saat itu, yang lebih 
menonjol dalam memberikan teguran-teguran baik bersifat tertulis maupun lisan lebih banyak dilakukan oleh Biro Pengembangan Perbankan Syariah Bank Indonesia daripada DPS sendiri. Padahal, DSN dan DPS mempunyai kewenangan untuk melaksanakan tugasnya sebagai badan pengawas syariah. Sebagai contoh teguran tertulis dari Bank Indonesia tentang pelaksanaan akad murabahah. Pada fatwa DSN memang tidak disebutkan bahwa pelaksanaan akad murabahah antara bank dengan nasabahnya itu harus dilakukan dengan cara (setelah akad murabahah ditandatangani) bank yang membeli dan membayar (harga beli bank) langsung kepada pemasok yang kemudian setelah pemasok menyerahkan barangnya kepada nasabah, nasabah berhutang kepada bank sebesar harga jual bank sesuai akad.

Contoh tersebut menurut Karnaen Perwataatmaja merupakan bukti dari belum adanya penjabaran secara teknis dari fatwa DSN, sehingga DPS tidak dapat melakukan tugasnya secara efektif dan efisien. Keputusan Dewan Syariah Nasional (DSN-MUI) mengenai petunjuk dan pelaksanaan penetapan anggota Dewan Pengawas Syariah pada lembaga keuangan syariah baru dikeluarkan pada tahun 2000. Dalam Petunjuk Pelaksanaan (JUKLAK) DPS sudah dicantumkan tugas, fungsi, dan wewenang DPS. Sehingga dengan surat keputusan tersebut DPS dapat melaksanakan tugasnya secara optimal, dan menjadikannya sebagai landasan operasional bagi seluruh lembaga keuangan syariah. Pada periode ini, DPS mempunyai peran utama yaitu sebagai lembaga fatwa. Efektivitas DPS dibuktikan dengan banyaknya fatwa diterbitkan oleh DPS Bank Muamalat.

DSN dalam hal ini merupakan salah satu institusi berskala nasional yang dijadikan payung bagi semua pihak dalam mengemban misi yang sangat mulia ini. Oleh karenanya, ia perlu pembenahan, perlu tenaga dan energi yang baru agar lebih kuat dan cepat. Dalam rangka tugas berat tersebut, menurut Syakir Sula, perlu upaya pembenahan DSN-MUI dalam dua hal, yaitu restrukturisasi dan repositioning.

\subsubsection{Restrukturisasi}

Upaya restrukturisasi DSN-MUI dalam menghadapi tugas dan tantangan yang cukup berat memang diperlukan. Pertama DSN-MUI bertugas mengawasi dan bermitra dengan lembaga keuangan syariah yang notabene diurus oleh praktisipraktisi yang profesional. Oleh karena itu, mitra kerjanyapun harus mengimbangi secara profesional. Badan Pelaksana Harian DSN perlu dipimpin oleh seorang executive director yang diambil dari kalangan profesional, digaji yang layak, dan benar-benar bekerja secara full time untuk DSN-MUI dengan manajemen modern.

\subsubsection{Repositioning}

DSN-MUI bukan hanya sebagai institusi pembuat fatwa di bidang ekonomi syariah, tetapi juga diharapkan sebagai lembaga riset, yang dapat memberikan kontribusi konsep-konsep baru ekonomi syariah. Oleh karenanya, rekrutmen terhadap pakar-pakar syariah dan praktisi yang mumpuni, mempunyai visi 
keumatan yang jelas menjadi sangat penting. Ulama-ulama yang faqih dan saleh benar-benar diharapkan berperan aktif di DSN-MUI. Tidak hanya itu, DSN-MUI juga perlu membangun integritasnya agar berwibawa di hadapan umat, bukan sebagai corong yang dimanfaatkan atau memanfaatkan pemerintah. Tetapi sebagai institusi yang berfungsi mengawasi dan mengembangkan ekonomi syariah. Dengan adanya legalitas perbankan syariah yang demikian kuat, perlu kiranya memberikan independensi kepada DSN-MUI, sehingga mampu memberikan kontribusi dan peran serta dengan institusi-institusi lainnya seperti BI dan Depkeu.

Kesepakatan antara MUI dan Bank Indonesia, BI menempatkan DSN-MUI sebagai lembaga yang bertanggungjawab dalam hal-hal menyangkut syariah, menempatkan posisi DSN-MUI menjadi sangat strategis dan sentral dalam hal pengembangan ekonomi syariah di negeri ini. Dalam pengembangan lembaga keuangan syariah, BI jauh lebih maju dibandingkan Departemen Keuangan. Salah satunya dapat dilihat dimana BI telah menempatkan pejabat setingkat direktur untuk menangani bank-bank syariah, sementara Departemen Keuangan sama sekali belum ada pejabat setingkat Kasubdit yang dikhususkan untuk menangani asuransi-asuransi syariah.

Berkaitan dengan aspek kepatuhan pada prinsip syariah, dilaksanakan melalui implementasi standar akad dan penyusunan penilaian tingkat kesehatan yang sesuai karakteristik bank syariah. Inisiatif ini didukung dengan memperkuat harmonisasi fatwa DSN dengan regulasi perbankan syariah.

Menurut Adiwarman Karim dalam Briefcase Book Edukasi Profesional Syariah,tidak mudah bertanggung jawab atas pengawasan syariah mengingat demikian kompleksnya transaksi perbankan. Menimpakan beban berat ini hanya kepada Dewan Pengawas Syariah bukanlah cara yang realistis. Pengawasan syariah sepatutnya merupakan tanggung jawab bersama semua stake holders. Selain DPS yang bertanggung jawab pada aspek syariahnya, maka untuk aspek aspek operasional pengawasan syariah paling tidak harus dilakukan oleh audit internal bank, direktur kepatuhan, bahkan komisaris harus ikut menjaga kepatuhan syariah. Audit eksternal yang dilakukan oleh kantor akuntan publik juga tidak boleh melewatkan begitu saja adanya pelanggaran atas kepatuhan syariah. Dan tentunya Bank Indonesia bertanggung jawab sebagai pemegang otoritas perbankan. Semua institusi ini sesuai kompetensi dan wewenangnya masingmasing harus bahu-membahu menjalankan fungsi pengawasan syariah.

\section{Penutup}

Penelitian ini telah berhasil menjawab proposisi utama yang diajukan sebelumnya. Pertama, Dewan Pengawas Syariah KSPPS bahwa sebagian besar pendidikan formal DPS yakni strata 1 dan sebagian besar porsi dipilih dari tokoh agama. Temuan lain yang menarik bahwa sebagian besar juga DPS belum pernah mengikuti pelatihan pengawasan syariah. Kedua, kinerja Dewan Pengawas Syariah 
KSPPS di ASKOWANU Jepara secara berkala melakukan pengawasan satu tahun 2 kali. Temuan lain menunjukkan pengawasan DPS terhadap SOP produk penghimpunan dan penyaluran dana telah dilakukan untuk memastikan bahwa telah sesuai dengan ketentuan fatwa DSN-MUI. Selain itu, setiap Rapat Akhir Tahun (RAT) DPS membuat pernyataan/opini syariah atas operasional yang dilakukan KSPPS.

Memang saat ini peran DPS di masing-masing lembaga keuangan syariah dinilai masih sangat minim, karena DPS hanya didominasi oleh ulama, padahal selain diisi oleh ulama DPS bisa diisi oleh ahli ekonomi dan perbankan syariah, dengan adanya perpaduan ini menjadikan jalan roda pengawasan lebih optimal, jika adanya perpaduan ini maka diharapkan ke depan akan ada ijtihad jama'i, yang hasilnya juga lebih maksimal dan bagus untuk perkembangan lembaga keuangan Syariah.

Inilah yang harus ditangani BI, DSN MUI dan lembaga keuangan syariah sendiri. Oleh karena itu, Undang-Undang yang memposisikan DPS yang demikian strategis, harus diimplementasikan dengan tepat dan cepat. Untuk itu setiap manajemen lembaga keuangan syariah harus melakukan formalisasi peran dan keterlibatan DPS dalam memastikan pengelolaan risiko ketidakpatuhan atas peraturan dan prinsip Syariah.

Perbedaan mendasar antara DSN dengan DPS dalam mengawasi lembaga ekonomi ataupun lembaga keuangan Syari'ah terletak pada wewenang yang dimiliki oleh masing-masing Dewan. DSN berwenang untuk menetapkan dan mengeluarkan fatwa-fatwa hukum Islam tentang kegiatan ekonomi dan keuangan. Sedangkan DPS hanyalah bertugas mengawasi pelaksanaan fatwa DSN tersebut dilapangan pada lembaga ekonomi dan lembaga keuangan syari'ah. Fungsi DSN memberikan tugas kepada DPS untuk (1) melakukan pengawasan secara periodik pada lembaga keuangan syariah, (2) mengajukan usul-usul pengembangan lembaga keuangan syariah kepada pimpinan lembaga yang bersangkutan dan kepada DSN; (3) melaporkan perkembangan produk dan operasional lembaga keuangan syariah yang diawasinya kepada DSN sekurang-kurangnya dua kali dalam satu tahun anggaran;(4) merumuskan permasalahan yang memerlukan pembahasan dengan DSN. Sayangnya, fungsi DSN dan DPS belum berjalan secara optimal. Pada saat itu, yang lebih menonjol dalam memberikan teguran-teguran baik bersifat tertulis maupun lisan lebih banyak dilakukan oleh Biro Pengembangan Perbankan Syariah Bank Indonesia daripada DPS sendiri. Padahal, DSN dan DPS mempunyai kewenangan untuk melaksanakan tugasnya sebagai badan pengawas syariah.

Karena pengembangan lembaga keuangan syariah masih dalam tahap awal, maka sistem dan mekanisme pengawasan lembaga keuangan syariah masih belum 
lengkap dan perlu banyak penyempurnaan. Oleh karena itu, upaya pengembangan pengawasan perbankan syariah oleh BI akan terus dilakukan secara berkesinambungan dengan mengembangkan dan menyempurnakan tools dan sistem pengawasan, serta meningkatkan kompetensi dan mengembangkan etika pengawasan.Men gingat aspek pengawasan terhadap lembaga ekonomi dan lembaga keuangan syari'ah memiliki kekhususan, yaitu meliputi aspek keuangan dan administrasi di satu sisi, dan aspek penerapan syari'ah di sisi yang lain. Maka pengawasan terhadap lembaga-lembaga keuangan yang berlabelkan Syari'ah harus lebih ketat. Maka dari itu DSN harus menjadi lembaga yang independen, memiliki kekuatan hukum yang pasti dan tidak tergantung kepada lembaga lainnya, sehingga peranan dan fungsinya untuk memberikan fatwa-fatwa tentang suatu produk atau jasa keuangan syari'ah benar-benar sesuai dengan ajaran Islam.

\section{Daftar Pustaka}

Danupranata, Gita. (2013). Manajemen Perbankan Syariah. Salemba Empat: Jakarta.

DSN-MUI. (2018). Modul Pelatihan Pengawas Syariah untuk Lembaga Keuangan Syariah: Koperasi Syariah. Tim DSN-MUI

Fatarib, Husnul. (2017). Revitalisasi Peran dan Fungsi DewanPengawas di Lembaga Keuangan Syari'ah Kota Metro."Jurnal el-Hekam”, Vol. II, No. 1.

Hidayat, Farid. (2016). “Alternative Sistem Pengawasan pada KoperasiSimpan Pinjam dan Pembiayaan Syariah (KSPPS) dalamMewujudkan Shariah Compliance." Jurnal Mahkamah, Vol.2, No. 1.

Hadi, Imam Abdul. (2011). "Kedudukan dan Wewenang Lembaga Fatwa (DSN-MUI) pada Bank Syariah.” Economic: JurnalEkonomi dan Hukum Islam, Vol. 1, No. 2.

Hidayat, Farid. (2016). “Alternative Sistem Pengawasan pada Koperasi Simpan Pinjam dan Pembiayaan Syariah (KSPPS) dalamMewujudkan Shariah Compliance." Jurnal Mahkamah, Vol.2, No. 1.

Ismanto, Kuat. (2015). "Pengelolaan Baitul Maal pada Baitul Maal WaTamwil (BMT) di Kota Pekalongan." Jurnal Penelitian Vol.12, No. 1.

Mujib, Abdul. (2017). "Dewan Pengawas Syariah (DPS) pada LembagaKeuangan Mikro Syariah di Wilayah Jawa Tengah." Jurnal Az Zarqa', Vol. 9, No. 1

Soemitra, Andri. (2017). Bank \& Lembaga Keuangan Syariah. EdisiKedua. Kencana: Depok. 
Umam, Khatibul. (2015). "Urgensi Standarisasi Dewan Pengawas Syariah dalam Meningkatkan Kualitas Audit Kepatuhan Syariah." Panggung Hukum: Jurnal Perhimpunan Mahasiswa Hukum Indonesia. Vol.1, No.2.

Prastiwi, Iin Emy. (2017). "Pengaruh Independensi Dewan Pengawas Syariah Dalam Mewujudkan Good Corporate Governance untuk Meningkatkan Kinerja BMT". Jurnal Ilmiah Ekonomi Islam Vol. 03 NO. 01.

Muhammad Firdaus Dkk. (2007). Sistem dan MekanismePengawasan Syariah . Jakarta: Renaisan. 